\title{
PENGENALAN PENYAKIT MENULAR SEKSUAL HUMAN IMMUNODEFICIENCY VIRUS-ACQUIRED IMMUNODEFICIENCY SYNDROME DI BUNDA MULIA SCHOOL JAKARTA
}

\author{
Alya Dwiana ${ }^{1}$, Ernawati ${ }^{2}$, Andriana KD \\ ${ }^{1}$ Bagian Ilmu Faal, Fakultas Kedokteran, Universitas Tarumanagara Jakarta \\ Email: alyad@fk.untar.ac.id \\ ${ }^{2}$ Bagian Ilmu Kesehatan Masyarakat, Fakultas Kedokteran, Universitas Tarumanagara Jakarta \\ Email: ernawati@fk.untar.ac.id \\ ${ }^{3}$ Bagian Obstetri \& Ginekologi, Fakultas Kedokteran, Universitas Tarumanagara Jakarta \\ Email: andrianakd@gmail.com
}

\begin{abstract}
The trend of the prevalence of cases of sexually transmitted diseases (STDs) of Human Immunodeficiency VirusAcquired Immunodeficiency Syndrome (HIV-AIDS) in the population aged 15-49 years increased from 0.16\% to $0.43 \%$ in 2013 and will continue to increase. Many doctors and scientists have stated how important comprehensive prevention efforts are, before the prevalence of HIV STDs in the Asia-Pacific region increased to 10 million sufferers by 2020. Several factors influence the occurrence of HIV-AIDS STDs among adolescents, one of which is the lack of accurate information. Therefore, health education, especially sexual education and healthy living behaviors are teachings that can help adolescents to deal with life problems that originate from sexual drive and relationships. Education about how HIV-AIDS STDs are transmitted and prevented is the main weapon against HIV-AIDS STDs, because there is no treatment or vaccine that can prevent the spread of HIV-AIDS STDs. Counseling about STD HIVAIDS is carried out at Bunda Mulia School, which is one of the youth communities that can be used as an example of efforts to prevent STD HIV-AIDS early. Prevention is carried out by interactive counseling in the form of discussions and question and answer sessions, which aim to provide a clear understanding for teenage students as well as teachers and school staff on how to prevent transmission of HIV-AIDS STDs. Before and after counseling, pre-test and posttest are held to assess whether there is a change in understanding of STD HIV-AIDS. The activity was followed by 88 students from grade 10-12. Overall, there was an increase in the knowledge of participating students about STD HIVAIDS with an average point of 1.34 to 1.55 after participating in counseling activities. So it can be concluded that the objectives of extension activities have been achieved.
\end{abstract}

Keywords: Sexually Transmitted Diseases; HIV; AIDS; teenager; interactive counseling

\begin{abstract}
ABSTRAK
Kecenderungan prevalensi kasus Penyakit Menular Seksual (PMS) Human Immunodeficiency Virus-Acquired Immunodeficiency Syndrome (HIV-AIDS) pada penduduk usia 15-49 tahun meningkat dari $0.16 \%$ menjadi $0.43 \%$ di tahun 2013 dan akan terus semakin meningkat. Banyak dokter dan ilmuwan telah menyatakan betapa pentingnya upaya pencegahan yang menyeluruh, sebelum prevalensi PMS HIV di wilayah Asia pasifik meningkat menjadi 10 juta penderita pada tahun 2020. Beberapa faktor yang mempengaruhi terjadinya PMS HIV-AIDS di kalangan remaja salah satunya adalah kurangnya informasi yang akurat. Maka dari itu, pendidikan kesehatan terutama pendidikan seksual dan perilaku hidup sehat merupakan pengajaran yang dapat menolong remaja untuk menghadapi masalah hidup yang bersumber dari dorongan seksual dan pergaulan. Pendidikan tentang bagaimana PMS HIV-AIDS ditularkan dan dicegah adalah senjata utama melawan PMS HIV-AIDS, karena tidak ada pengobatan atau vaksin yang dapat mencegah penyebaran PMS HIV-AIDS. Penyuluhan mengenai PMS HIV-AIDS dilakukan di Sekolah Bunda Mulia yang merupakan salah satu komunitas remaja yang dapat dijadikan sebagai contoh upaya pencegahan PMS HIV-AIDS secara dini. Pencegahan dilakukan dengan penyuluhan yang interaktif berupa diskusi dan sesi tanya jawab, yang bertujuan untuk memberikan pemahaman yang jelas bagi para siswa remaja serta guru dan petugas sekolah mengenai cara mencegah penularan PMS HIV-AIDS. Sebelum dan sesudah penyuluhan, diadakan pre-test dan post-test untuk menilai apakah ada perubahan dalam pemahaman mengenai PMS HIV-AIDS. Kegiatan diikuti oleh 88 siswa/i kelas 10-12. Secara keseluruhan terjadi peningkatan pengetahuan siswa peserta mengenai PMS HIVAIDS dengan rata-rata poin 1.34 menjadi 1.55 setelah mengikuti kegiatan penyuluhan. Sehingga dapat disimpulkan bahwa tujuan kegiatan penyuluhan telah tercapai.
\end{abstract}

Kata kunci: Penyakit Menular Seksual, HIV, AIDS, remaja, penyuluhan interaktif 


\section{PENDAHULUAN}

Sejak tahun 1990, World Health Organization (WHO) telah menyampaikan suatu istilah yang disebut sebagai "The Global Burden Disease (GBD)" yang menjadi suatu standar untuk melaporkan informasi kesehatan global yang terkait dengan penyakit-penyakit yang menjadi ancaman bagi masyarakat luas, diantaranya akibat lingkungan (fisik dan non-fisik) termasuk yang disebabkan oleh gangguan nutrisi, gaya hidup/perilaku serta modernisasi. Salah satu penyakit yang prevalensiya terus meningkat dan perlu mendapatkan perhatian serius dalam GBD adalah Acquired Immune Deficiency Syndrome (AIDS). ${ }^{1}$

Human Immunodefisiensi Virus (HIV) adalah virus yang menyerang sistem kekebalan tubuh manusia dan melemahkan kemampuan tubuh untuk melawan berbagai jenis penyakit. Penyakit Menular Seksual (PMS) AIDS (Aquired Immune Defisiensy Syndrome), sebenarnya bukan suatu penyakit tetapi merupakan kumpulan dari gejala-gejala penyakit yang disebabkan oleh infeksi berbagai macam organisme serta keganasan lain yaitu turunnya daya tahan tubuh penderita. PMS HIV menyerang dan merusak sel-sel limfosit $\mathrm{T}$ yang mempunyai peran penting dalam sistem kekebalan seluler. ${ }^{2}$ PMS HIV ditularkan melalui hubungan seksual dengan penderita tanpa alat pengaman, transfusi darah yang terkontaminasi, penggunaan jarum suntik yang terkontaminasi, serta antara ibu penderita PMS HIV dan bayinya selama kehamilan, melahirkan dan menyusui. ${ }^{2}$

Organisasi dunia WHO (World Health Organization) dan UNAIDS (United Nations Programme On HIV/AIDS), memberi peringatan bahaya kepada 3 negara di Asia seperti Cina, Vietnam dan Indonesia yang saat ini disebut-sebut berada pada titik tertinggi infeksi HIV. Saat ini di seluruh dunia diperkirakan lebih dari 40 juta orang mengidap HIV/AIDS. Sekitar 75\% yang tertular PMS HIV/AIDS berada di kawasan Asia Pasifik dan Afrika. Lebih dari 20 juta jiwa telah meninggal karena PMS AIDS. ${ }^{2}$ Wilayah Asia Pasifik memiliki jumlah penderita PMS HIV dan AIDS kedua terbesar di dunia setelah Afrika. Pada akhir tahun 2007 diperkirakan sekitar 4,9 juta orang di wilayah Asia Pasifik menderita PMS HIV dan AIDS. Selama tahun 2007 saja sekitar 440.000 orang di antaranya baru saja terinfeksi. Tidak ada satu pun negara di wilayah Asia Pasifik terbebas dari PMS HIV dan AIDS. ${ }^{3}$ Kecenderungan prevalensi kasus PMS HIV pada penduduk usia 1549 meningkat.

Kasus PMS HIV/AIDS di Indonesia selama delapan tahun terakhir mulai dari tahun 2005-2012 menunjukkan adanya peningkatan. Kasus baru infeksi PMS HIV meningkat dari 859 kasus pada tahun 2005 menjadi 21.511 kasus di tahun 2012. Sedangkan kasus baru PMS AIDS meningkat dari 2.639 kasus pada tahun 2005 menjadi 5.686 kasus pada tahun 2012. Prof. dr. Tjandra Yoga Aditama melaporkan sejak pertama kali ditemukan (1987) sampai dengan September 2012, kasus PMS HIV-AIDS tersebar di 341 dari 497 kabupaten/kota di seluruh (33) provinsi di Indonesia. Kasus PMS HIV, dari Juli sampai dengan September 2012 jumlah kasus baru PMS HIV yang dilaporkan sebanyak 5.489 kasus. Persentase faktor risiko PMS AIDS tertinggi adalah hubungan seks tidak aman pada heteroseksual $(81,9 \%)$, penggunaan jarum suntik tidak steril pada Penasun $(7,2 \%)$, dari ibu (positif HIV) ke anak $(4,6 \%)$, dan LSL $(2,8 \%) .{ }^{6}$ Selain itu, pada awal tahun 2009 , prevalensi kasus HIV pada penduduk usia 15-49 tahun hanya 0,16\% dan meningkat menjadi $0,30 \%$ pada tahun 2011 , meningkat lagi menjadi $0,32 \%$ pada tahun 2012 , dan terus meningkat manjadi 0,43\% pada tahun 2013.

Namun angka Case Fatality Rate (CFR) PMS AIDS di Indonesia mengalami penurunan dari 13,65\% pada tahun 2004 menjadi 0,85\% pada tahun 2013. Hal ini disebabkan karena potensi cukup baik yang dimiliki Indonesia dalam pengendalian PMS HIV-AIDS seperti telah memiliki persiapan yang cukup baik mencakup tata laksana penanganan pasien, tenaga kesehatan, pelayanan kesehatan (khususnya Rumah Sakit), dan laboratorium kesehatan. Setidaknya terdapat 
empat laboratorium yang sudah terakreditasi dengan tingkat keamanan biologi 3 (BSL 3), yakni Laboratorium Badan Litbang Kesehatan, Institute of Human Virology and Cancer Biology (IHVCB) Universitas Indonesia, Institut Penyakit Tropis Universitas Airlangga, dan Lembaga Biologi Molekuler Eijkman. ${ }^{4}$ Saat ini di Indonesia, terdapat 39.434 penyandang PMS AIDS hingga tahun 2012. Jumlah kematian akibat AIDS di dunia pada tahun 2006 ialah sekitar 2,6 juta. Angka mortalitas penyandang PMS AIDS di Indonesia adalah 7.293 hingga September $2012 .{ }^{6}$

Banyak dokter dan ilmuwan telah menyatakan betapa pentingnya untuk mengambil tindakan sedini mungkin untuk pencegahan penyebaran PMS HIV-AIDS. Tanpa upaya pencegahan yang menyeluruh, prevalensi HIV di wilayah Asia Pasifik akan meningkat hampir mencapai 10 juta penderita pada tahun $2020 .{ }^{5}$ Fakta telah berbicara bahwa banyak anak muda telah melakukan hubungan seks. Banyak dari mereka tetap melakukan hubungan seks sekalipun telah dilarang dan diingatkan tentang risiko bahayanya. Keyakinan bahwa anak muda yang melakukan hubungan seks di luar nikah adalah pemberontak, pengganggu, gagal di bidang akademik tidak sepenuhnya benar; sama halnya dengan anak muda yang pandai, yang baik-baik saja belum tentu juga mereka tidak melakukan hubungan seks. Masa remaja adalah masa pencarian identitas dan bereksperimen. Remaja cenderung menganggap dirinya paling hebat, paling benar, paling kuat, sehingga pada umumnya mereka bersedia mengambil risiko lebih besar dari yang lainnya. Tidak hanya anak berumur 16 tahun ke atas yang telah melakukan hubungan seks, remaja di bawah umur 15 tahun pun sudah melakukan hubungan seks. ${ }^{7}$

Peningkatan angka kejadian PMS HIV/AIDS pada remaja dikarenakan banyaknya media yang memberikan informasi yang salah seperti majalah, buku, dan film pornografi yang memaparkan kenikmatan berhubungan seks tanpa mengajarkan tanggungjawab yang harus disandang dan resiko yang harus dihadapi. Hasil penelitian Mohammad Ali pada tahun 2011, 21-30\% remaja di Indonesia khususnya kota Bandung, Jakarta dan Yogyakarta telah melakukan hubungan seks pranikah. ${ }^{2}$

Beberapa faktor yang mempengaruhi terjadinya PMS HIV/AIDS di kalangan remaja salah satunya adalah kurangnya informasi yang akurat. Maka dari itu pendidikan kesehatan terutama pendidikan seksual merupakan pengajaran yang dapat menolong remaja untuk menghadapi masalah hidup yang bersumber dari dorongan seksual. Pendidikan tentang bagaimana PMS AIDS ditularkan dan dicegah adalah senjata utama melawan PMS HIV/AIDS, karena tidak ada pengobatan atau vaksin yang dapat mencegah penyebaran PMS HIV/AIDS. ${ }^{8}$ Walaupun sudah 20 tahun sejak PMS HIV dan AIDS pertama kali muncul di wilayah Asia Pasifik, banyak anak muda masih belum pernah mendengar tentang hal ini. Beberapa di antaranya masih juga salah paham dan percaya tentang mitos PMS HIV. Di banyak negara banyak wanita muda kurang tahu tentang PMS HIV dibanding pria muda. Padahal mereka termasuk rentan atau berisiko tinggi untuk terinfeksi PMS HIV. Untuk melindungi diri mereka sendiri, mereka membutuhkan kejujuran dan informasi yang benar.

Oleh karena itu kami mengambil langkah utama yang penting untuk melindungi generasi muda adalah dengan memberikan pendidikan seks melalui pendekatan tentang masalah seksualitas dan pendidikan seks harus diarahkan pada pencegahan PMS HIV, kesehatan reproduksi dan stereotip gender. Bunda Mulia International School terletak di Jalan Lodan raya No. 2 Lodan Center, daerah Ancol Jakarta Utara. Total jumlah murid Sekolah Bunda Mulia mulai dari play grup sampai SMA sekitar 900 siswa. Sebagian besar siswa-siswi merupakan usia remaja, dengan kultur dan kebiasaan berbeda-beda, sehingga merupakan target yang sesuai untuk dilakukannya penyuluhan mengenai penyebaran PMS HIV-AIDS. Siswa-siswi yang dapat terkena langsung dampak dari penyakit seksual ini akan diberikan pengetahuan, wawasan dan informasi tentang isu PMS HIV dan AIDS oleh pakar kesehatan. 


\section{METODE PELAKSANAAN}

Fakultas Kedokteran Universitas Tarumanagara mengadakan kegiatan Pengabdian Masyarakat (Abdimas) berupa penyuluhan interaktif mengenai PMS HIV-AIDS. Kegiatan Abdimas ini merupakan salah satu perwujudan tridharma perguruan tinggi di bidang Pengabdian dan Pelayanan kepada Masyarakat (P2M) yang memerlukan peran serta dosen, karyawan dan mahasiswa. Kegiatan ini ditujukan kepada siswa-siswi Bunda Mulia International School, yang berusia antara 15-18 tahun, yang beresiko terhadap penyebaran penyakit menular seksual khususnya HIV-AIDS.

Luaran yang hendak dicapai pada kegiatan Abdimas ini adalah memberikan penyuluhan terkait informasi PMS HIV-AIDS yang diharapkan dapat memberi dampak positif, yaitu perubahan pola hidup sehingga dapat menambah pengetahuan dan menerapkannya dalam kehidupan sehari-hari. Kegiatan penyuluhan dan pelatihan dilakukan secara interaktif. Materi yang disampaikan terkait PMS HIV- AIDS disampaikan secara baik, menggunakan bahasa awam yang mudah dimengerti dan dilengkapi gambar-gambar yang informatif bagi remaja.

Kegiatan penyuluhan dilakukan di ruang Auditorium lantai 3 Bunda Mulia School yang telah mendapat persetujuan dari pihak sekolah. Kegiatan dilaksanakan pada hari Jumat tanggal 8 Februari 2019 pada pukul 07.30-12.00 WIB. Pada hari pelaksanaan, siswa-siswi dilakukan pendataan dan diberikan pre-test untuk menilai tingkat pengetahuan terhadap PMS HIV-AIDS. Setelahnya, siswa-siswi diberikan penyuluhan oleh pakar kesehatan dan dilakukan sesi diskusi serta tanya jawab. Pada akhir kegiatan, siswa-siswi diminta mengisi lembar post-test untuk mengetahui apakah telah terjadi peningkatan pengetahuan siswa-siswi terhadap PMS HIV-AIDS setelah penyuluhan tersebut.

\section{Area Presentasi}
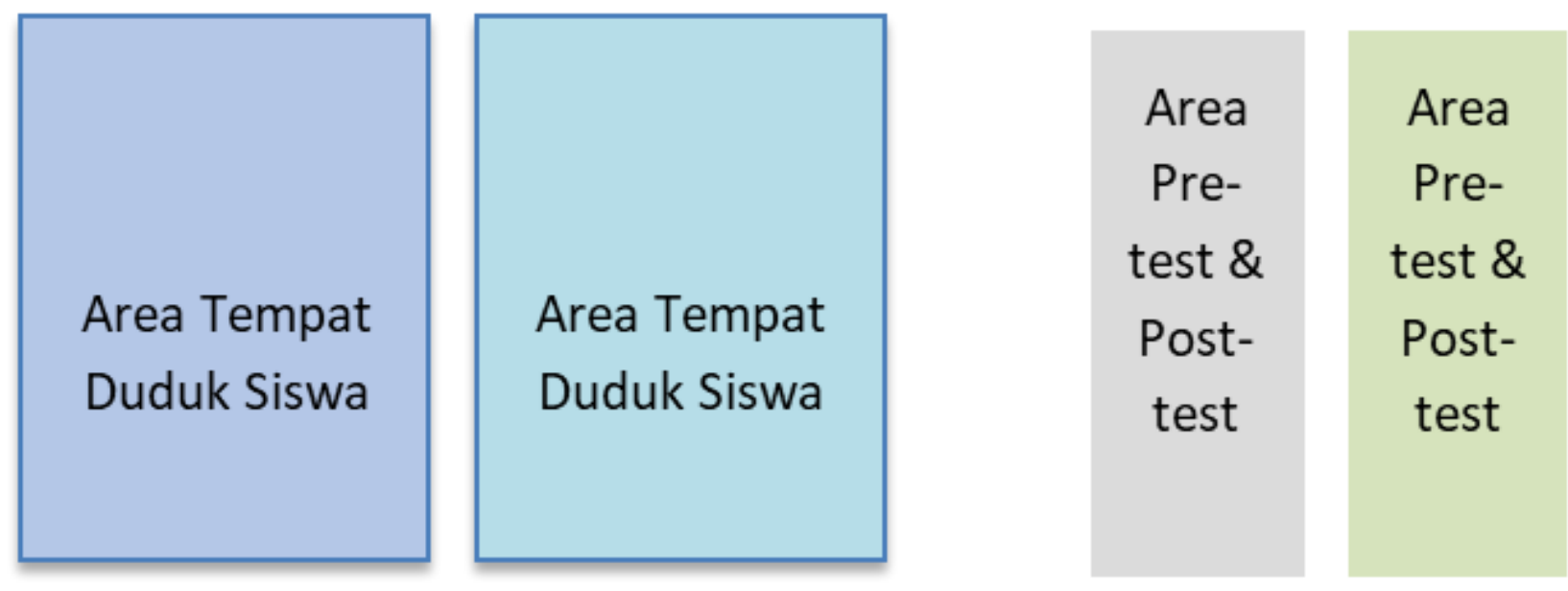

Gambar 1. Skema pelaksanaan penyuluhan kesehatan 


\section{HASIL YANG DIDAPATKAN}

Kegiatan penyuluhan diikuti oleh siswa-siswi kelas 10-12 Bunda Mulia School sebanyak 88 orang. Ada beberapa siswa yang diketahui telah pindah sekolah atau tidak dapat hadir pada hari tersebut karena beberapa alasan. Lebih dari separuh peserta yang menghadiri penyuluhan adalah berjenis kelamin laki-laki, yaitu sebanyak 50 siswa (56,82 \%). Sedangkan usia 15 tahun adalah yang terbanyak $(35,22 \%)$. (Lihat tabel 1)

Tabel 1. Karakteristik Peserta Penyuluhan

\begin{tabular}{cccc}
\hline No & Karakteristik & $\mathbf{N = 8 8}$ & $\mathbf{\%}$ \\
\hline 1. & Jenis Kelamin & & \\
& Laki-laki & 50 & 56,82 \\
& Perempuan & 38 & 43,18 \\
\hline 2. & Usia (tahun) & & \\
15 tahun & 31 & 35,22 \\
& 16 tahun & 28 & 31,82 \\
& 17 tahun & 23 & 26,14 \\
& 18 tahun & 3 & 3,41 \\
& Tidak menyebutkan & 3 & 3,41 \\
\hline
\end{tabular}

Sebelum dilakukan penyuluhan, siswa peserta diminta menjawab soal pre-test yang bertujuan untuk mengetahui sejauh mana pemahaman siwa mengenai PMS HIV-AIDS. Ada 12 pertanyaan yang diajukan yaitu: pengetahuan tentang PMS, siapa saja yang dapat terkena PMS, pengetahuan tentang HIV-AIDS, siapa saja yang dapat terkena HIV-AIDS, berapa kali seseorang dapat terkena PMS, berapa kali seseorang dapat terkena HIV-AIDS, cara penularan PMS, cara penularan HIVAIDS, bahaya PMS, bahaya HIV-AIDS, cara menghindari PMS dan cara menghindari HIV-AIDS. Setelah dilakukan penyuluhan, siswa peserta kembali diminta menjawab soal post-test dengan pertanyaan yang sama. Hal ini bertujuan untuk mengetahui apakah dengan mengikuti penyuluhan, siswa sudah lebih mengetahui dan paham mengenai PMS HIV-AIDS. Dari 88 siswa peserta penyuluhan, ada 1 orang yang tidak mengisi lembar pre-test (n-87) sedangkan saat post-test ada 4 orang yang tidak mengisi dengan lengkap $(n=83)$.

Berdasarkan hasil yang didapat, rata-rata terjadi peningkatan pengetahuan siswa terhadap PMS HIV-AIDS kecuali pada 3 pertanyaan yaitu: mengenai berapa kali seseorang dapat terkena HIVAIDS, cara penularan PMS dan cara menghindari HIV-AIDS (lihat Tabel 2). Untuk ketiga pertanyaan tersebut, siswa yang sebelumnya 'tahu' menjadi 'kurang tahu' dan bahkan 'tidak tahu'. Ada kemungkinan siswa masih kurang paham dalam membedakan antara PMS dan HIV-AIDS terutama mengenai cara penularan dan cara pencegahan penyakit tersebut. Namun untuk sembilan pertanyaan lainnya mengenai PMS HIV-AIDS, tingkat pengetahuan siswa mengalami peningkatan (dari 'tidak tahu' dan 'kurang tahu' menjadi 'tahu'). Secara keseluruhan rata-rata poin pengetahuan peserta meningkat dari 1.34 menjadi 1.55. (Lihat Tabel 2 dan Grafik 1)

Tabel 2. Pemahaman Siswa Mengenai PMS HIV-AIDS Sebelum dan Sesudah Mengikuti

Penyuluhan

\begin{tabular}{ccccc}
\hline No. & Pertanyaan & Respon & $\begin{array}{c}\text { Pre-Test } \\
(\mathrm{N}=87)\end{array}$ & $\begin{array}{c}\text { Post-Test } \\
(\mathrm{N}=83)\end{array}$ \\
\hline 1. & Apakah mengetahui tentang PMS? & Tidak Tahu & $12(13.80 \%)$ & $8(9.64 \%)$ \\
& & Kurang Tahu & $30(34.48 \%)$ & $20(24.10 \%)$ \\
& & Tahu & $45(51.72 \%)$ & $55(66.26 \%)$ \\
\hline 2. & Siapa yang dapat terkena PMS? & Tidak Tahu & $7(8.04 \%)$ & $5(6.02 \%)$ \\
& & Kurang Tahu & $16(18.40 \%)$ & $5(6.02 \%)$ \\
& & Tahu & $64(73.56 \%)$ & $73(87.95 \%)$ \\
\hline 3. & Pengetahuan tentang HIV-AIDS & Tidak Tahu & $8(9.20 \%)$ & $5(6.02 \%)$ \\
\hline
\end{tabular}




\begin{tabular}{|c|c|c|c|c|}
\hline & & Kurang Tahu & $\begin{array}{l}26(29.88 \%) \\
53(6.22 \%\end{array}$ & $\begin{array}{l}19(22.89 \%) \\
59(71.08 \%)\end{array}$ \\
\hline \multirow{3}{*}{4.} & Siapa yang dapat terkena HIV-AIDS & Tidak Tahu & $5(5.75 \%)$ & $4(4.81 \%)$ \\
\hline & & Kurang Tahu & $29(33.33 \%)$ & $16(19.27 \%)$ \\
\hline & & Tahu & $53(60.92 \%)$ & $63(75.90 \%)$ \\
\hline \multirow[t]{3}{*}{5.} & Berapa kali seseorang dapat terkena PMS? & Tidak Tahu & $52(59.77 \%)$ & $1(1.20 \%)$ \\
\hline & & Kurang Tahu & $1(1.15 \%)$ & $1(1.20 \%)$ \\
\hline & & Tahu & $34(39.08 \%)$ & $81(97.60 \%)$ \\
\hline \multirow[t]{3}{*}{6.} & Berapa kali seseorang dapat terkena HIV- & Tidak Tahu & $25(28.73 \%)$ & $33(39.76 \%)$ \\
\hline & AIDS? & Kurang Tahu & $3(3.45 \%)$ & $3(3.61 \%)$ \\
\hline & & Tahu & $59(67.82 \%)$ & $47(56.63 \%)$ \\
\hline \multirow[t]{3}{*}{7.} & Bagaimana cara penularan PMS? & Tidak Tahu & $20(22.98 \%)$ & $8(9.64 \%)$ \\
\hline & & Kurang Tahu & $8(9.20 \%)$ & $20(24.10 \%)$ \\
\hline & & Tahu & $59(67.82 \%)$ & $55(66.26 \%)$ \\
\hline \multirow[t]{3}{*}{8.} & Bagaimana cara penularan HIV-AIDS? & Tidak Tahu & $14(16.09 \%)$ & $4(4.82 \%)$ \\
\hline & & Kurang Tahu & $40(45.98 \%)$ & $33(39.76 \%)$ \\
\hline & & Tahu & $33(37.93 \%)$ & $46(52.87 \%)$ \\
\hline & Apakah tahu bahaya PMS? & Tidak Tahu & $21(24.14 \%)$ & $8(9.64 \%)$ \\
\hline & & Kurang Tahu & $41(47.13 \%)$ & $46(55.42 \%)$ \\
\hline & & Tahu & $24(27.59 \%)$ & $29(34.94 \%)$ \\
\hline & Apakah tahu bahaya HIV-AIDS? & Tidak Tahu & $14(16.09 \%)$ & $7(84.33 \%)$ \\
\hline & & Kurang Tahu & $15(17.24 \%)$ & $12(14.46 \%)$ \\
\hline & & Tahu & $58(66.67 \%)$ & $64(77.11 \%)$ \\
\hline & Bagaimana cara menghindari PMS? & Tidak Tahu & $18(20.69 \%)$ & $3(3.61 \%)$ \\
\hline & & Kurang Tahu & $17(19.54 \%)$ & $15(18.07 \%)$ \\
\hline & & Tahu & $52(59.77 \%)$ & $65(78.31 \%)$ \\
\hline & Bagaimana cara menghindari HIV-AIDS? & Tidak Tahu & $18(20.69 \%)$ & $3(3.61 \%)$ \\
\hline & & Kurang Tahu & $54(62.07 \%)$ & $71(85.54 \%)$ \\
\hline & & Tahu & $15(17.24 \%)$ & $9(10.84 \%)$ \\
\hline \multirow[t]{3}{*}{13.} & RATA-RATA PENGETAHUAN & Tidak Tahu & 17.83 & 7.42 \\
\hline & KESELURUHAN PESERTA & Kurang Tahu & 23.33 & 21.75 \\
\hline & & Tahu & 44.50 & 54.67 \\
\hline
\end{tabular}

Grafik 1. Perubahan Pengetahuan Siswa Mengenai PMS HIV-AIDS

\section{Pengetahuan Mengenai PMS}
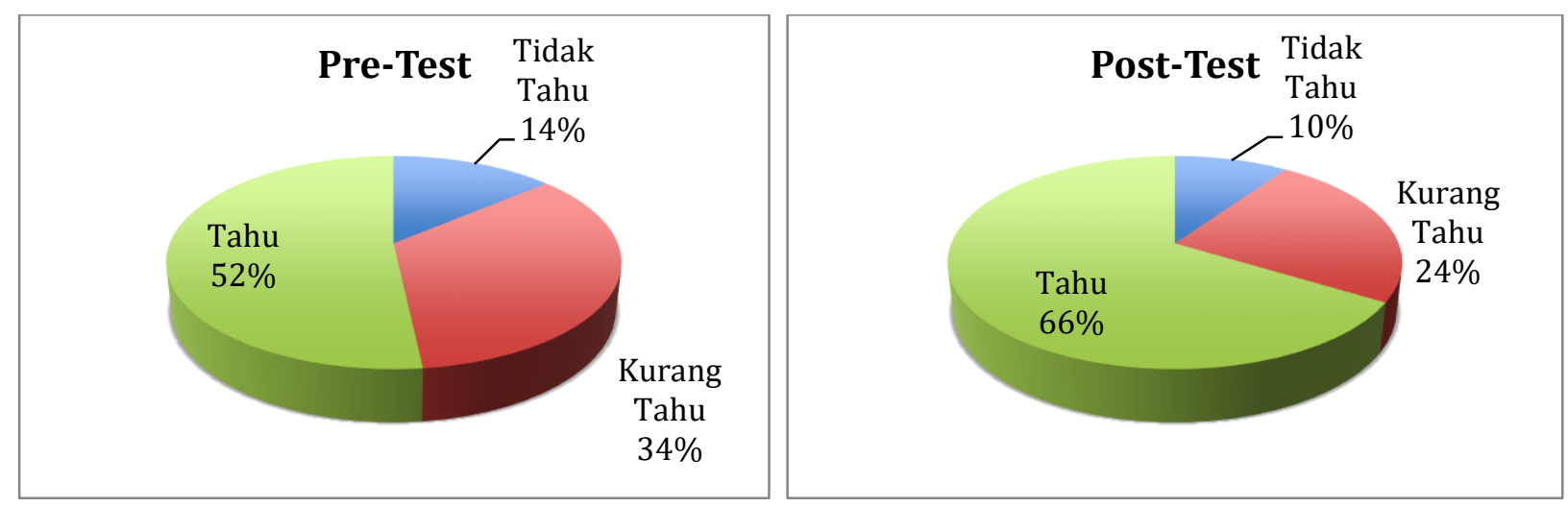


\section{Siapa Yang Dapat Terkena PMS}
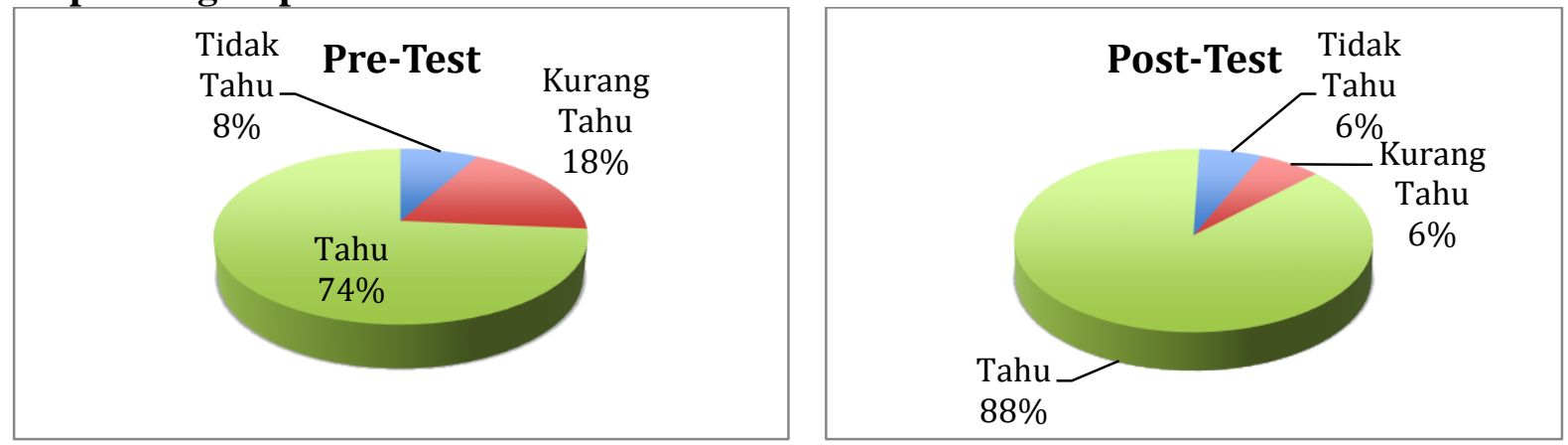

\section{Pengetahuan Tentang HIV-AIDS}

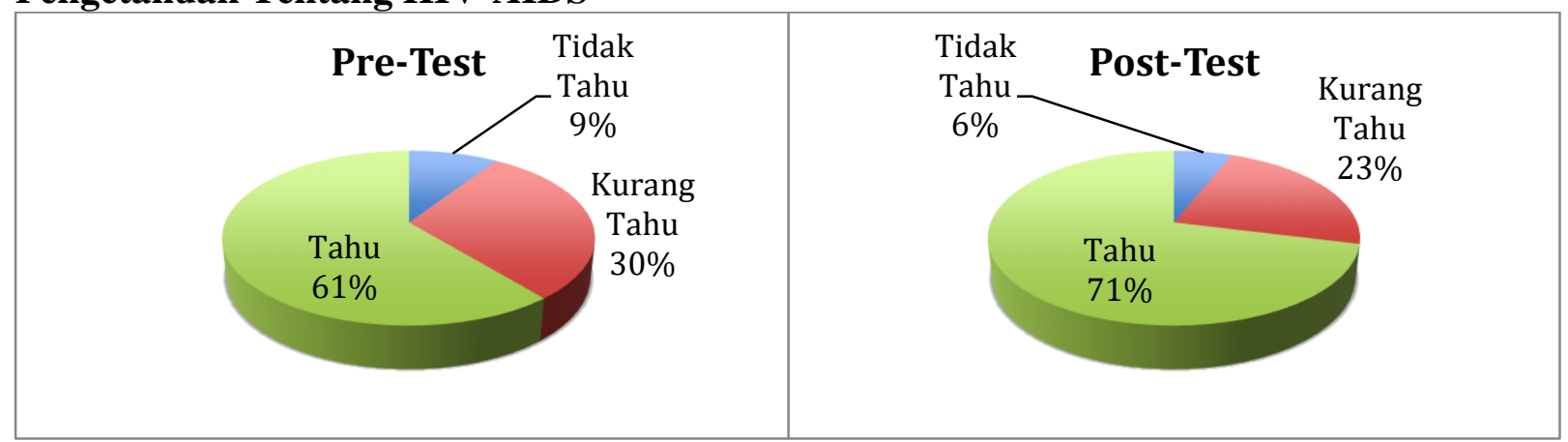

Siapa Yang Dapat Terkena HIV-AIDS

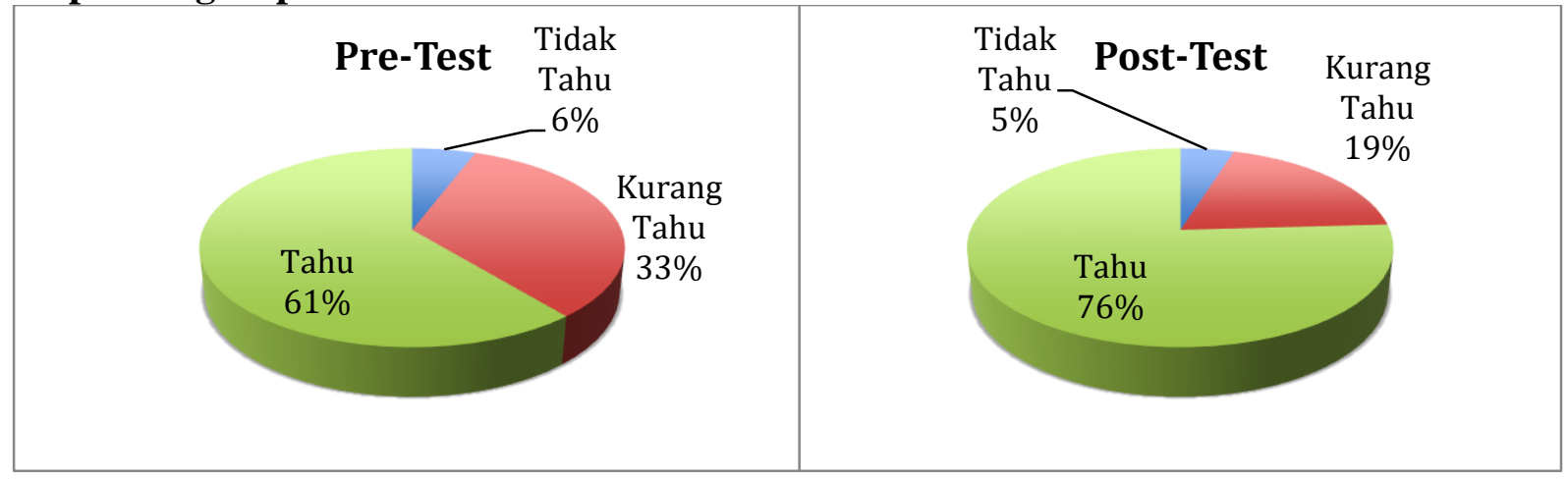

\section{Berapa Kali Seseorang Dapat Terkena PMS}

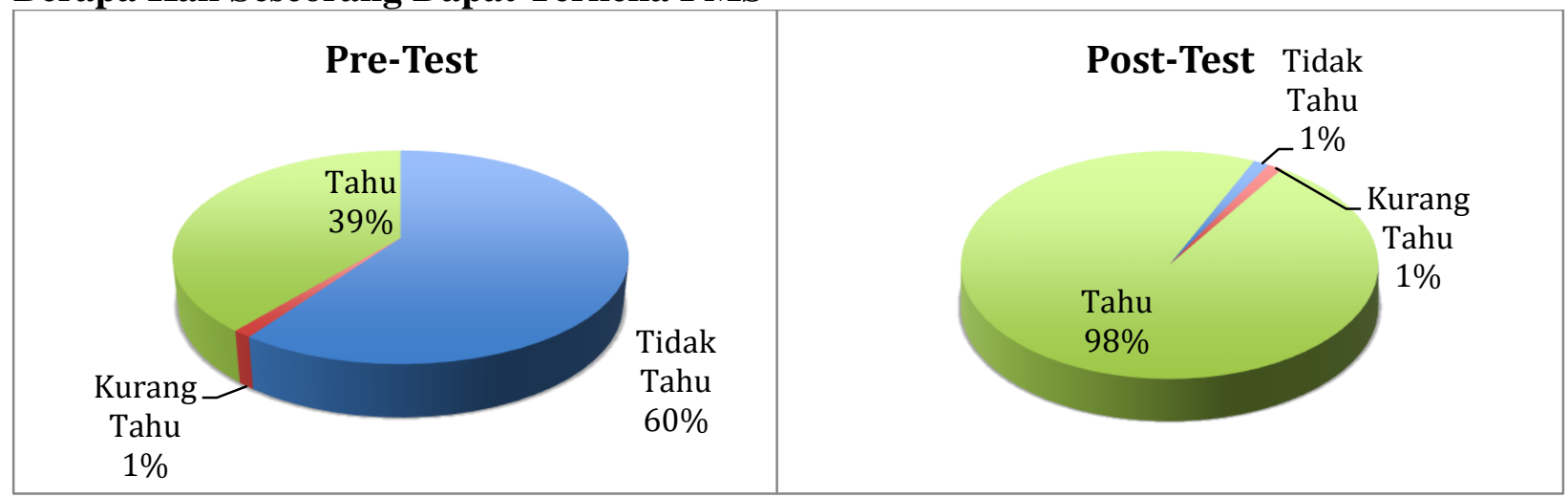


Berapa Kali Seseorang Dapat Terkena HIV-AIDS

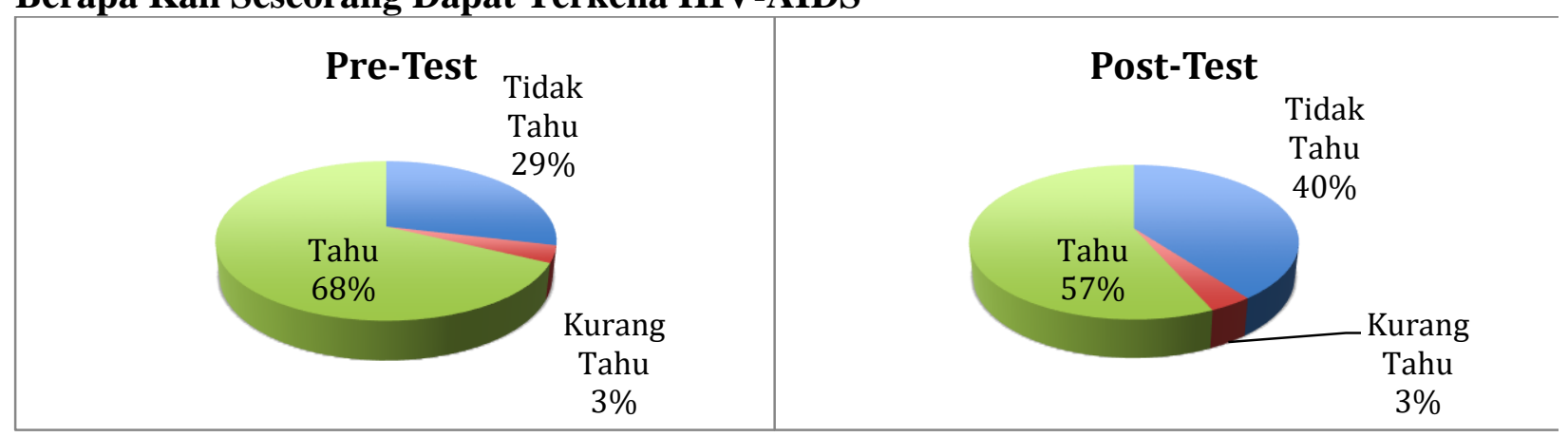

\section{Cara Penularan PMS}

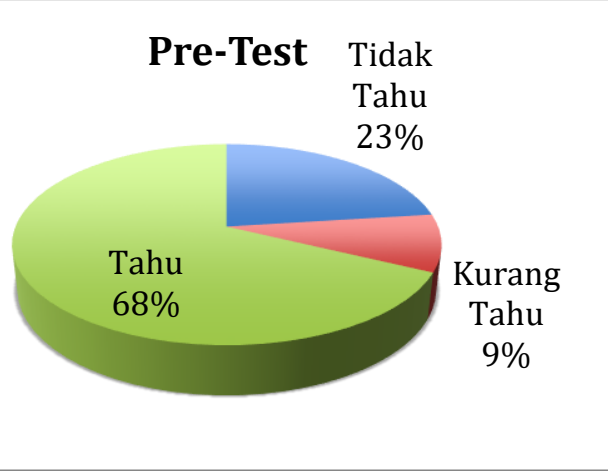

\section{Cara Penularan HIV-AIDS}

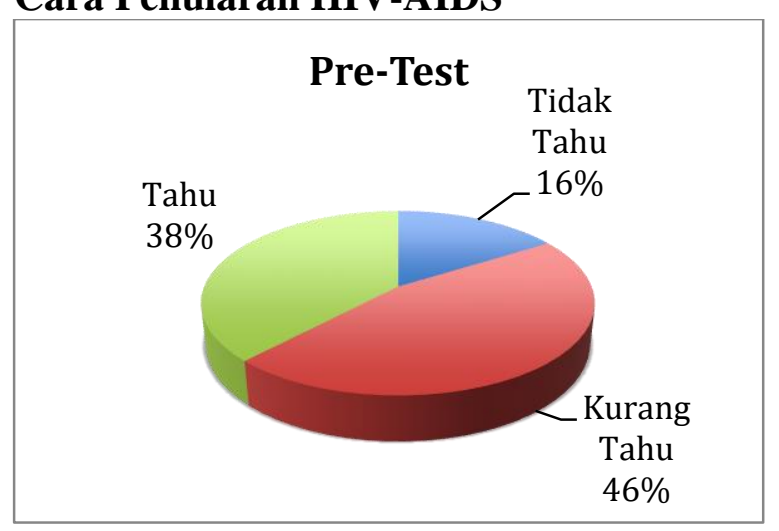

\section{Bahaya PMS}

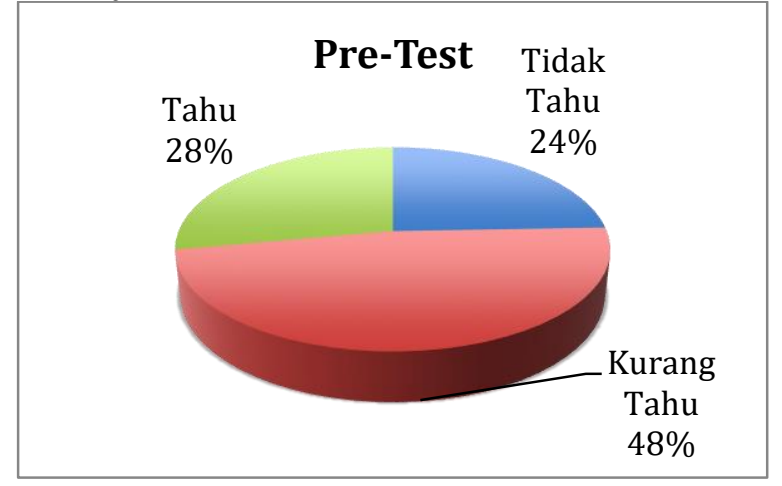

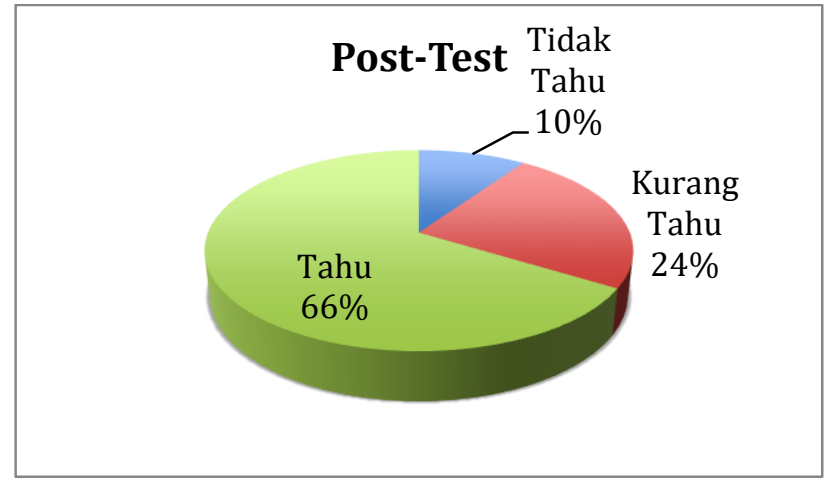

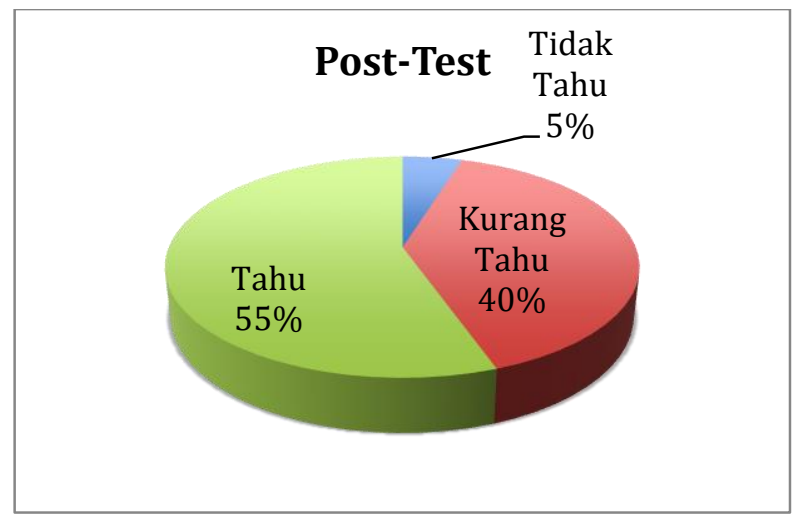

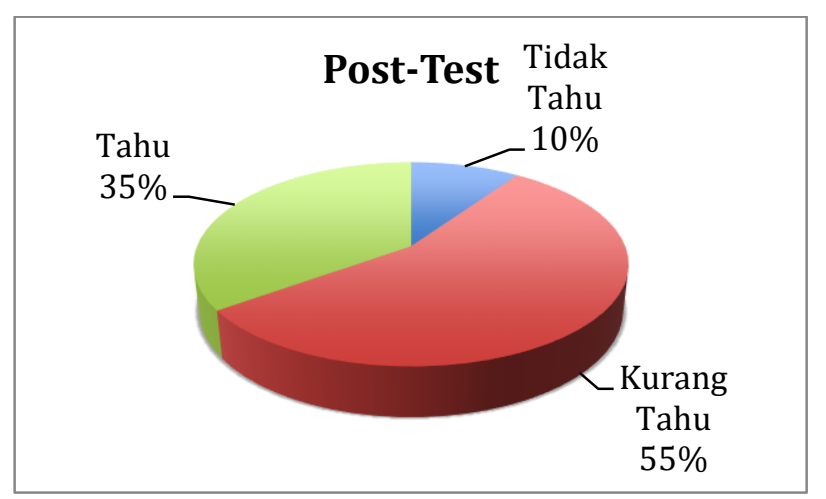




\section{Bahaya HIV-AIDS}
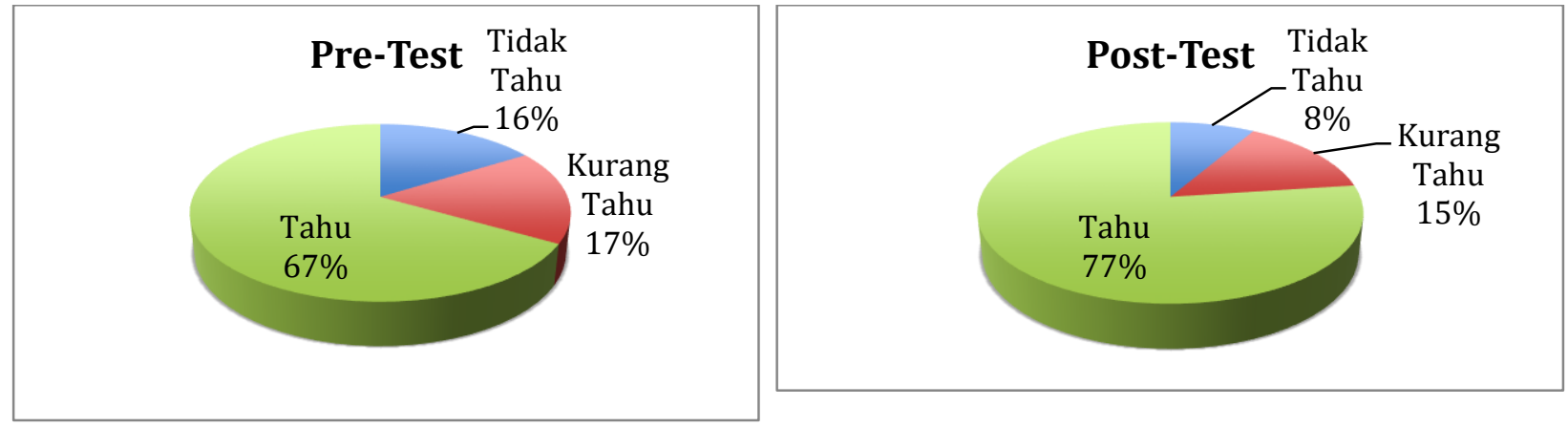

\section{Cara Menghindari PMS}
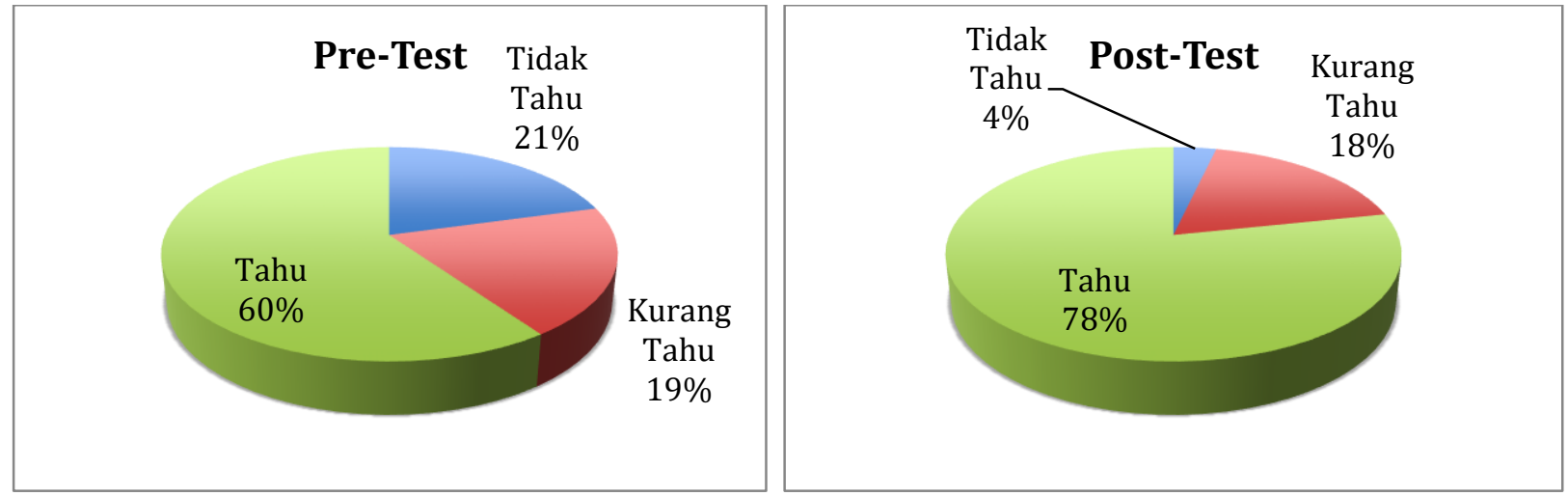

\section{Cara Menghindari HIV-AIDS}
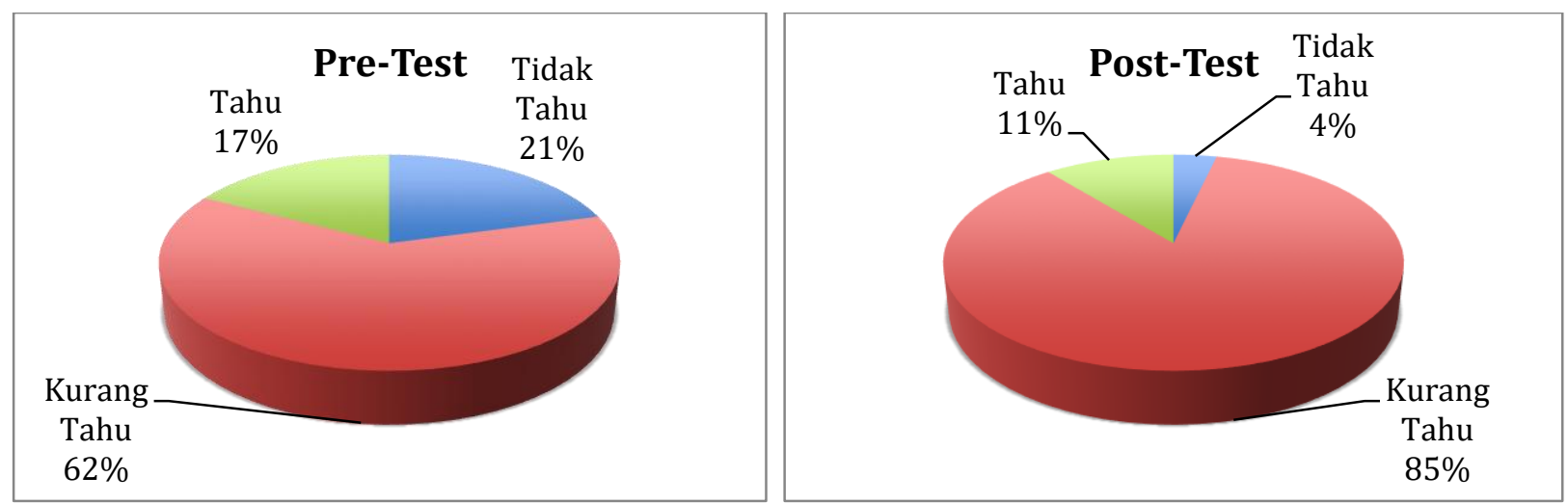


\section{RATA-RATA Pengetahuan Peserta}

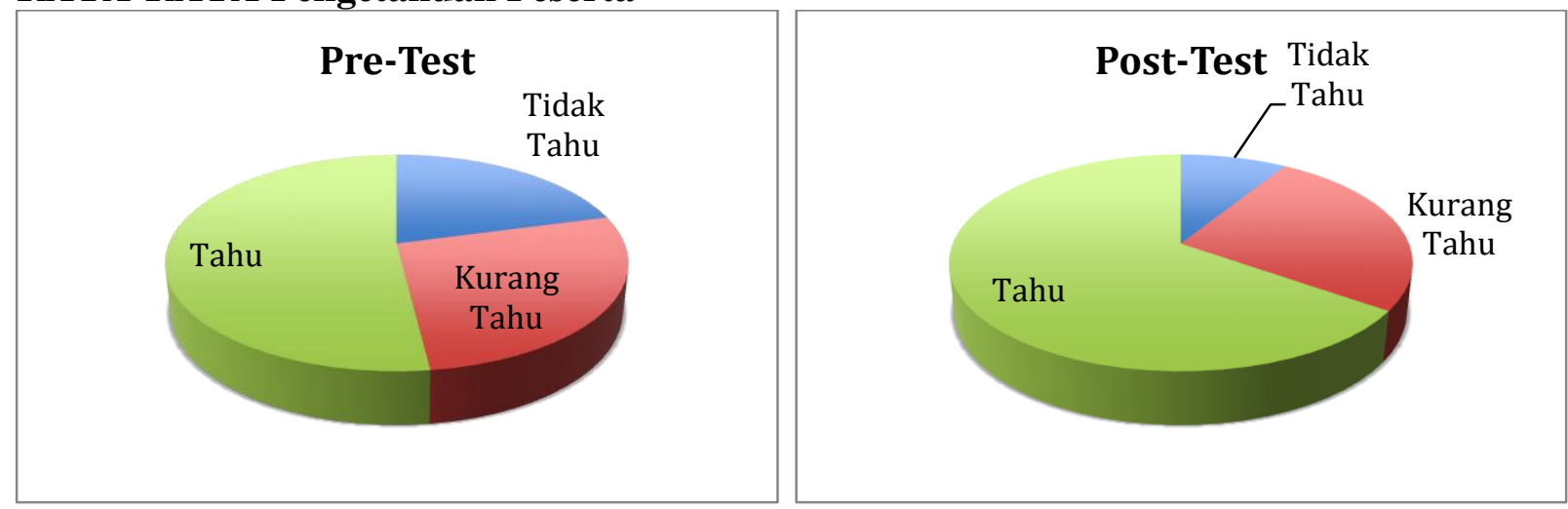

\section{LUARAN YANG DICAPAI}

Pelaksanaan kegiatan pengabdian berjalan sesuai perencanaan serta berjalan dengan lancar dan tertib. Target peserta tercapai walau ada beberapa siswa yang tidak hadir karena sudah pindah sekolah atau karena alasan lainnya. Secara keseluruhan terjadi peningkatan pengetahuan peserta terhadap PMS HIV-AIDS.

\section{KESIMPULAN DAN SARAN}

Kegiatan pengabdian kepada masyarakat dengan topik "Pengenalan Penyakit Menular Seksual (PMS) Human Immunodeficiency Virus - Acquired Immunodeficiency Syndrome (HIV-AIDS) di Lingkungan Bunda Mulia International School Jakarta" dilaksanakan dengan baik dan lancar pada hari Jumat tanggal 8 Februari 2019. Kegiatan dihadiri oleh 88 siswa-siswi Bunda Mulia School kelas 10-12. Kegiatan penyuluhan ini lebih banyak dihadiri siswa berjenis kelamin laki-laki $(56,82 \%)$ dan berusia 15 tahun $(35,22 \%)$.

Untuk kegiatan PKM berikutnya, disarankan untuk dilakukan penyuluhan yang lebih detil dengan bahasa yang lebih mudah dimengerti mengenai perbedaan dan persamaan penyakit menular seksual (PMS) dan Human Immunodeficiency Virus - Acquired Immunodeficiency Syndrome (HIV-AIDS). Untuk mendukung pemahaman siswa/remaja dapat dilakukan kegiatan role play, diskusi kelompok atau sesi debat.

\section{Ucapan Terima Kasih (Acknowledgement)}

Penulis mengucapkan terima kasih kepada Direktorat Penelitian dan Pengabdian kepada Masyarakat (DPPM) sebagai sponsor dan Dekan Fakultas Kedokteran Universitas Tarumanagara (FK-UNTAR) yang mendukung penuh kegiatan penyuluhan ini. Tidak lupa penulis memberikan apresiasi kepada Kepala Sekolah, Guru serta Anak Didik SMA Bunda Mulia International School dan Mahasiswa FK-UNTAR yang telah banyak membantu sehingga kegiatan ini dapat berjalan dengan lancar.

\section{REFERENSI}

Kummar, V., Abbas, AK., Aster JC. (2015) Robbins and Cotran; Pathologic basic of disease 9th edition. Saunders Elsevier, Philadelphia.

Kemenkes RI. (2014) Pusat data dan informasi Kementrian Kesehatan, Situasi dan analisis HIV/AIDS.

UNAIDS/WHO (2007). AIDS epidemic update. UNAIDS, Geneva. 
Kementerian Kesehatan Republik Indonesia. (2015). Rencana Strategis Kementerian Kesehatan tahun 2015-2019.

Komisi AIDS Asia. (2018) Redefining AIDS in ASIA crafting on effective response. Oxford University Press, New Delhi.

Ditjen PP dan PL Kemenkes RI. (2012) Statistik kasus HIV/ AIDS di Indonesia. Kemenkes RI. Jakarta.

Wellings, K., Collumbien, M., Slaymaker, E., Singh, S., Hodges, Z., Patel, D., and Bajos, N. (2006). Sexual behaviour in context: A global perspective. Lancet, 368 (9548), 1706-1728.

Abdeyaz. (2013). Promosi kesehatan teori dan aplikasi. Rineka cipta, Jakarta.

Notoatmodjo, S. (2010). Pendidikan dan perilaku kesehatan. Rineka Cipta, Jakarta. 